PART 7

Control 
Kaarel Vanamölder - 9789004362871

Downloaded from Brill.com $04 / 26 / 2023$ 01:51:48PM via free access 


\title{
Establishing a State-Controlled Network for News Trading in the Swedish Baltic Provinces in the Late Seventeenth Century: Causes and Consequences
}

\author{
Kaarel Vanamölder
}

The beginning of printed periodicals in Estonia and Latvia dates back to the last quarter of the seventeenth century when the majority of the territories of the present Baltic States were part of the Swedish kingdom. For historical reasons, German culture and language dominated in the Livonian, Estonian and Ingerian provinces. The first periodical newspapers printed in the provincial centres - Riga, Tallinn and Narva - were also published in German and they have been rightfully dealt with in the wider context of the early modern German press. Their layout and contents did not differ from the other newspapers of the time and were influenced by the printing houses of Hamburg (and Altona) which was the main centre of communication and news production and reproduction in the Baltic Sea region during the seventeenth century. ${ }^{1}$

The historiography of the news press in the Swedish overseas provinces has been under-researched for a long time - no significant information has been added to the primary introductory survey of the newspapers undertaken nearly a century ago. ${ }^{2}$ The topic has been covered mainly by researchers of Baltic German background, while for their colleagues from Estonia and Latvia the history of the press in a foreign language has not been of much interest until recently. The state of research is furthermore characterised by the fact that the newspapers published in the provincial centres have been looked at

1 See, for example, Else Bogel and Elger Blühm, Die deutschen Zeitungen des 17. Jahrhunderts (2 vols., Bremen: Schünemann, 1971); Holger Böning and Emmy Moepps, Deutsche Presse. Bibliographische Handbücher zur Geschichte der deutschsprachigen periodischen Presse von den Anfängen bis 1815. Bd. 1: Hamburg. Kommentierte Bibliographie der Zeitungen, Zeitschriften, Intelligenzblätter, Kalender und Almanache sowie biographische Hinweise zu Herausgebern, Verlegern und Druckern periodischer Schriften. Von den Anfängen bis 1765, Bd. 1.1 (Stuttgart-Bad Cannstatt: Frommann-Holzboog, 1996), pp. XI-Xxx.

2 See, for example, Arno Rafael Cederberg, Die Erstlinge der estländischen Zeitungsliteratur (Tartu: C. Mattiesen, 1922), pp. 3-16; Arend Buchholtz, Geschichte der Buchdruckerkunst in Riga 1588-1888 (Riga: Müller, 1890), pp. 165-173. 
independently and in an antiquarian way, mainly by listing the extant issues. ${ }^{3}$ There is also very little information on news consumption in the provincial centres before the publication of local newspapers.

In the present chapter I will focus upon the conditions of publishing of the newspapers from the provincial centres: Rigische Montags (Donnerstags) Ordinari Post Zeitung (1680-1681) and its successor Rigische Novellen (1681-1710), both published in Riga, and the Tallinn newspaper Reval( $i)$ sche Post-Zeitung (1689-1710), connected to the newspaper in Riga. ${ }^{4}$ The chapter will not focus upon the Narva newspaper Narvische Post-Zeitungen, about which next to

3 See, for example, Friedrich Koch, 'Die Anfänge des baltischen deutschen Zeitungswesens', Baltische Monatshefte (1938), pp. 67-81; Roland Seeberg-Elverfeldt, 'Dreihundert Jahre deutschbaltische Presse', Zeitschrift für Ostforschung, 26 (1977), pp. 651-670; Endel Annus, 'Tidningsväsendet i Baltikum före 1710', in Endel Annus and Esko Häkli (eds.), Den estniska boken genom seklerna (Helsinki: Helsingfors universitetsbibliotek, 1995), pp. 53-65; Endel Annus, 'Die im Baltikum bis 1710 erschienenen Zeitungen', in Aleksander Loit and Helmut Piirimäe (eds.), Die schwedischen Ostseeprovinzen Estland und Livland im 16.-18. Jahrhundert (Stockholm: Centre for Baltic Studies, 1993), pp. 423-432; Oskar Grosberg, Die Presse Lettlands. Mit einem geschichtlichen Rückblick (Riga: Baltischer Verlag, 1927), pp. 8-11; Johannes von Eckardt, Beiträge zur Geschichte des deutsch-baltischen Zeitungswesens (Ludwigshafen am Rhein: Waldkirch, 1929), pp. $5^{-6}$; V.I. Simonov, 'K istorii vozniknoveniia pervoi pechatnoi periodicheskoi gazety v Rige', Izvestiia Akademii nauk Latviiskoi ssR, 9 (446) (1984), pp. 118-130; M. [A.] Taube, 'Rīgas pirmie laikraksti kā kultūrvēstures avots (XVII un XVIII gs)', in E. Arājs (ed.), Grāmatas un to krātuves (Riga: Zinātne, 1966), pp. 65-129; Valda Rudziša, 'Deutschsprachige Zeitungen in Riga aus dem 17. und 18. Jahrhundert', in Jörg Riecke and Britt-Marie Schuster (eds.), Deutschsprachige Zeitungen in Mittel- und Osteuropa. Sprachliche Gestalt, historische Einbettung und Kulturelle Tradition (Berlin: Weidler, 2005), pp. 79-89; Kaarel Vanamölder, Kommunikatsiooniväli Rootsi Läänemere-provintsides 17. sajandi lõpul. - Reval(i)sche Post-Zeitung varauusaegse informatsioonikandjana (Tartu: Tartu Ülikooli Kirjastus, 2012) <http://dspace.ut.ee/handle/10062/27085>.

4 The issues of the Riga newspapers can be found at the National Library of Latvia and the Latvian Academy of Sciences Library, in the Russian State Archive of Ancient Acts and in the Royal Library of Sweden in Stockholm. See for example Endel Annus (ed.), Eestis ilmunud saksa-, vene-ja muukeelne perioodika 1675-1940 (Tallinn: Eesti Teaduste Akadeemia Raamatukogu, 1993), pp. 228-234. The digitalised versions of the newspapers can be accessed from the Bremen University Library homepage in the collection "Zeitungen des 17. Jahrhunderts" $<$ http://brema.suub.uni-bremen.de/zeitungenı7>. The name of the Tallinn newspaper had two different spellings: Revalsche Post-Zeitung (1689-1699?) and Revalische Post-Zeitung (1699?-1710). Due to this a combined form of the name, Reval( $i)$ sche Post-Zeitung, is used in this article. The issues of the Tallinn newspaper can be found at the Tallinn University Academic Library Baltica collection, Estonian Historical Archives, the Royal Library of Sweden in Stockholm, Uppsala University Library and in the Russian State Archive of Ancient Acts. See Annus, Eestis ilmunud, p. 201. The digitalised copies of the newspapers are available at $<$ http://brema.suub.uni-bremen.de/zeitungenı7>. 
nothing is known beside the fact that it was published (proven by one extant newspaper issue from 1702$).{ }^{5}$ The chapter is an attempt to treat the press history of the Swedish overseas provinces as fully as possible, taking a closer look at the reasons and causes of newspaper publishing, and to place this within the wider context of early modern press history. It endeavours to answer the questions: which control mechanisms were appropriated by the Swedish state (and when and why), how were the new news media modelled and distributed, how successful were these activities, and how did they influence the publishing of newspapers in the overseas provinces? To find the answers I have not so much looked upon the extant numbers of the newspapers as the extant archive materials in Estonia, Latvia and Sweden, concerning the newspapers' publication, selling and distribution.

\section{The Establishing of the Riga Newspaper in 1680 and the pre-1680 Town News Market}

In May 1680 Charles XI sent a letter to the governor-general Christer Horn in which he expressed discontent with the contents and forwarding of the news in Livonia during the recent Scanian War $\left(1675^{-1679)}{ }^{6}\right.$ This document marks the birth of a centrally controlled new press in Riga: according to the order of the king, a newspaper henceforth had to be published by an official who was specially appointed for this task, and the censorship of the contents was to be carried out by the office of the governor-general. The first state-appointed newspaper purveyor was Christoph Prescher, who had worked in the royal field office during the war. He fulfilled the task for the next four years and was followed by the castle court assessor Georg Ruvius who was appointed by a royal privilege issued in 1684 and who (or whose widow) held the right until the closing of the newspaper in $1710 .^{7}$

Christoph Prescher and Georg Ruvius were therefore both officials acting in accordance with a royal privilege, state-appointed Zeitungers who held a monopoly on publishing a newspaper. Their main task became gathering the

5 See the historiography of the Narva newspaper: Enn Küng, 'Johann Köhler ja Narva trükikoda 1695-1705', in Enn Küng (ed.), Läänemere provintside arenguperspektiivid Rootsi suurriigis 16/17. sajandil II (Tartu: Eesti Ajalooarhiiv, 2006), pp. 336-363 (here 348-349). The extant issue of the Narva newspaper (Narvische Post-Zeitungen No 17; 23 April 1702) can be found in a digitalised version at $\langle$ http://brema.suub.uni-bremen.de/zeitungenı7 $>$.

6 Latvijas Universitātes Akadēmiskā Bibliotēka [Academic Library of the University of Latvia, henceforth LUAB], MS. 1140, 1, No 7; for a transcription of the document see: Riksarkivet [Swedish National Archives, henceforth RA], Riksregistraturet: 1112.1/B/452 (1680), pp. 394-395.

7 Vanamölder, Kommunikatsiooniväli, pp. 208-209. 
news items from other sources, and editing and compiling a newspaper based on the items. The privilege did not include crown-supported recompense, assuming the mediating and selling of news guaranteed sufficient income. In this respect the state-appointed editor in Riga differed from the ordinary early modern news merchant acting on private initiative for whom the sale of information was an additional income source beside their main occupation (postmaster, printer or other).

Although the above-mentioned letter of the king is not completely unknown in historiography, ${ }^{8}$ this document, rich in information, deserves further mention. While subjecting the publication of the newspaper to the control of a central power, the document also points out the reasons for the decision and this enables us to sketch the way in which the Riga news market functioned up until that time. Prior to the document, the sale of printed newspapers in Riga was criticised for the faulty news that they contained: “...and not to publish, as it has happened so far, a lot of unfounded things in the journals and newspapers printed in Riga...." ${ }^{9}$ The source could be interpreted in different ways. From the purely grammatical construction of the sentences it can be assumed that (several) newspapers were printed in Riga prior to May 1680. This piece of information is of great interest because in the historiography so far, only postmaster Jakob Becker's failed attempt to publish a newspaper in the town in $163^{2}$ is known. ${ }^{10}$ For the following period of half a century there is no information and according to the present state of knowledge, people in Riga were limited to reading newspapers brought from other towns, mainly the newspaper from Königsberg."

The letter addressed to the governor-general was intended to outline the upcoming tasks of Prescher, and to guarantee the full support of the local authorities the document names the printer and the postmaster as news distributors whose competing and harmful activities were to be stopped. The document clearly states that henceforth only Prescher had the right to garner information for newspapers in Riga and Livonia and publish them after they

8 Taube, 'Rīgas pirmie', pp. $65^{-129}$.

9 “... und nicht wie bishero geschehen, viele ungegründete dinge in denen dort zu Riga drückenden Gazetten und Zeitungen, debitiret werden mögen ..." (LUAB, MS. 1140, 1, No 7).

10 About Jacob Becker see Enn Küng, "The Attempts to Establish Private Postal System in the Swedish Baltic Sea Provinces in the Beginning of the 1630s', in Priit Raudkivi et al. (eds.), Sõnasse pü̈̈tud minevik: In honorem Enn Tarvel (Tallinn: Argo, 2009), pp. 178-189.

11 Vanamölder, Kommunikatsiooniväli, pp. 28-31. 
had been censored by the office of governor-general. ${ }^{12}$ The printer was strictly (ernstlich) forbidden to accept newspapers for publishing from anybody else but Prescher. In the same context the postmaster was forbidden to transcribe (verschreiben) and accept other newspapers. ${ }^{13}$

Riga was doubtless a trading metropolis of the Baltic Sea region during the early modern period, its population being thrice that of Stockholm..$^{14}$ Due to the excellent position of Riga in the network of postal routes, the leading overseas postal office was situated there, providing the main connections with Western Europe and vice versa. The Western or so-called German post (teutsche post) was regularly distributed overland, especially when the navigation season ended..$^{15}$ Riga was also one of the main communication channels between Russia and Europe. In addition to correspondence, the Western European newspapers, which the Russian Head of Post had to supply to his government, travelled via Riga to Moscow. ${ }^{16}$

There is no doubt that news marketing and, by some means, the reproduction of news items took place in Riga prior to 1680 and this process was executed by the postmaster and printers - the traditional representatives of the early modern newspaper business. ${ }^{17}$ The Riga news market and people acting upon

12 "So haben Wir Ihme zu einiger ergetzlichkeit für solche drauf anwendende specen in gnaden vergönnet, daß Er und sonst niemand anders die Gazetten und Zeitungen dort in Liefland und Riga schreiben und nach dem Sie vorerst alda in der Gouvernements Cantzeley zur censur eingegeben, drucken zulaßen ..." (LUAB, MS. 1140, 1, No 7).

13 “... zu welchem ende Ihr nicht allein Unseren daselbigen Buchdrucker ernstlich inhibiren und verbiethen werdet, die Gazetten von niemand alß erwelten Prescher zum Druck anzunehmen und Ihme wieder ausfolgen zulaßen, besondern auch dem Postmeister nachdrücklich anbefehlet, daß weilen dergleichen Zeitungen und Nouvellen auf diese weise durch eine pertinente correspondence dort in loco füglicher können beygeschaffet werden, Er hiefüro keine Gazetten von Königsberg oder andere Örther verschreibe oder einkommen laße.", (LUAB, MS. 1140, 1, No 7).

14 Elisabeth Harder-Gersdorff, 'Riga als Handelsmetropole des Ostseeraums in der Frühen Neuzeit (16.-18. Jahrhundert)', in Ilgvars Misāns and Horst Wernicke (eds.), Riga und der Ostseeraum. Von der Gründung 1201 bis in die Frühe Neuzeit (Marburg: Verlag HerderInstitut, 2005), pp. 261-294; Robert I Frost, The Northern Wars: War, State and Society in Northeastern Europe, 1558-1721 (Harlow: Longman, 2000), p. 140.

15 See Enn Küng, “...mugavamaid teid, kui nüüd linnade vahel tarvitatakse, on vaevalt leida...": Postirevisjon Eesti- ja Liivimaal 1687.-1688. aastal', Tuna, 4 (2005), pp. 17-34 (23-25).

16 Enn Küng, 'Riia-Moskva postitüli Põhjasõja eelõhtul', Tuna, 4 (2006), pp. 12-24 (19-24).

17 In 1675 Riga had two printing houses: the royal printing press was established beside the town printing press by royal privilege, see Tiiu Reimo, 'Trükiprivileegidest Baltimaadel XVII-XVIII sajandil', Tartu Ülikooli Raamatukogu aastaraamat 1999 (2000), pp. 184-195 (188-189). 
it, as they are reflected in the king's letter, represent in reality a stereotypical early modern market town where different news items were sold and new ones compiled. Should we reverse the forbidding imperative of the source, we get a picture showing a Riga printer (or printers) accepting newspapers for publication and a postmaster transcribing and selling others, possibly handwritten news items. Taking into consideration Riga's role in long distance marketing and the Swedish postal network in the seventeenth century, the 'silence' prior to 1680 would seem extremely odd. It is possible and even expected that in addition to one newspaper, other news media reached Riga.

Another important question is why was it necessary to rearrange the news market of Riga in 1680 ? The historiography has considered the establishing of censorship in Riga as a measure against the nobility, and the first step towards the reduction of their power. ${ }^{18}$ This explanation may be unsatisfactory and shallow because the purpose of the early modern newspapers was not the coverage of and commenting upon the local news but the bringing of information in from outside. The main concern, therefore, was the better control of the information coming from abroad. The need to rearrange the ruling of the state, based on the recent results of the Scanian War, meant the establishing of absolutist power in Sweden. This, indeed, is a widespread viewpoint in the existing historiography. ${ }^{19}$ In this context, 1680 is a significant date when the Swedish Riksdag declined its constitutional power over Charles XI thereby opening the way to several important reforms. ${ }^{20}$ In the countries controlled by absolutist power the information of the central power targeted at the vast public was sought to be rigidly controlled which meant subjugating the publishing of newspapers to the direct and strict control of the state. It may be assumed therefore that the king's wish to 'rule' the news market should be seen, among the other means like the reduction of the powers of the nobility, as a manifestation of the king's sole power. The intervention of the royal power replaced the existing information business with a new reality, in which the traditional representatives of this business were pushed aside by the pressure inflicted by the central power, and a new monopoly for state-controlled newspapers and news distribution was established. With these steps the marketing of news in Riga was brought closer to the practices of Stockholm. ${ }^{21}$

18 Aleksander Loit, Kampen om feodalräntan. Reduktionen och domänpolitiken $i$ Estland 1655-1710 (Uppsala: Acta Universitatis Upsaliensis, 1975), pp. 97-98.

19 See for example Frost, The Northern Wars, pp. 216-225; Anthony F Upton, Charles XI and Swedish Absolutism (Cambridge: Cambridge University Press, 1998), pp. 11-50.

20 Upton, Charles XI and Swedish Absolutism, pp. 31-50.

21 Ann-Katrin Hatje, 'Von der königlichen Postzeitung zum "Swänska Argus". Ein Überblick über die Schwedische Presse im 17. und 18. Jahrhundert', in Martin Welke and Jürgen 
When looking at the king's decree as a whole, it appears that the discontent was caused by what was going on in the Riga news market in general rather than by the Königsberg newspaper read in the town which, nevertheless, remains the only geographically localised publication mentioned in the document. The desire caused by the Scanian War to block the distribution of the Königsberg newspaper in the Swedish provinces is understandable since Brandenburg-Prussia was among the opposition against Sweden in the conflict, a fact that was undoubtedly reflected in the choice of the news items for the Königsberg newspaper. The practical experience of the information war received during the conflict - presenting events in a positive light for the state and harmful to the opposition reputation in all possible ways, and establishing the image of aggressor in the printed media etc. - might have played an important role, as was noticed by contemporaries of the events. ${ }^{22}$ The experience of the Swedish information war was poignantly summarised by Gottfried Zenner in 1692: "even the Swedish king noticed that the Hamburg news writers were of more use during the recent Swedish-German war than could possibly have been achieved by the regiments". 23

\section{Prescher as the State Newspaper Editor / the Marketing Strategies of the New Newspaper}

Having become the sole Rigan official Zeitunger, Prescher had to realise his task. We will look now at how he tried to accomplish this. Although the information is scarce, certain strategies for selling the newspaper become evident. While preparing the publication of the actual newspaper sometime in October of 1680 , Prescher's immediate concern was trying to find subscribers to the

Wilke (eds.), 4oo Jahre Zeitung. Die Entwicklung der Tagespresse im internationalen Kontext (Bremen: Edition Lumière, 2008), pp. 205-221 (217-218).

See for example Astrid Blome, Das deutsche Rußlandbild im frühen 18. Jahrhundert. Untersuchungen zur zeitgenössischen Presseberichterstattung über Rußland unter Peter I. (Wiesbaden: Harrassowitz, 2000).

"Und gleichwie man von dem Hamburgischen Zeitungs-Schreiber in vorigem Schwedischen Teutschen Kriege nicht uneben gesaget/ der König in Schweden habe selbst bekennet/ dass er ihm mehr Nuzen geschaffet/ als zehen Regimenter nicht gethan; Also kann auch einer/ der entweder partheylisch und praejudirlich/ oder wider Warheit etwas in die Welt schreibet/ nicht geringen Schaden stifften". Gottfried Zenner, Novellen aus der gelehrten und curiösen Welt (Frankfurt and Gotha: Junius 1692), pp. 517-518; see also Johannes Weber, 'Kontrollmechanismen im deutschen Zeitungswesen des 17. Jahrhunderts. Ein kleiner Beitrag zur Geschichte der Zensur',Jahrbuch für Kommunikationsgeschichte, 6 (2004), pp. 56-73 (here p. 56). 
newspaper beyond Riga. It seems that he treated as his rightful market not only Livonia but the other overseas provinces such as Estonia and Ingeria.

The letter sent to the Estonian commercial centre, the Tallinn Town Council, in the beginning of November of the same year remains a good source. ${ }^{24} \mathrm{In}$ this document Prescher first sheds some light on the conditions of publishing the newspaper: by the decree of the king it was henceforth forbidden to bring Königsberg newspapers to the local post-office. After that Prescher recommended in a polite manner ("meine Arbeit unterdienstlich recommendiren zu durffen") that newspapers should be ordered from him for 6 state dalers per annum ("iarlich 6 Rthlr vons Stuck"). The sample issues of the new publication for Thursday and Monday were included with the letter. ${ }^{25}$ This is the first piece of information to confirm the printing the Riga newspaper as early as 1680 , which has only been a presumption within the historiography thus far. ${ }^{26}$

Prescher did not treat only the Tallinn Town Council as his target audience because in the latter part of the letter it was suggested that the magistrate should help to spread the information on the option of ordering the Riga newspaper among the townspeople, encouraging interested bodies to come forward. ${ }^{27}$ The aim of the letter was therefore to advertise the new newspaper as widely as possible in Tallinn and to find as many subscribers as possible. The sample issues added to the letter were supposed to speak for themselves.

It can be assumed that Prescher sent a similar advertising letter to the Ingerian commercial centre at Narva. The grounds for this assumption are given by the letter sent to the Narva magistrate from Riga on 30 December of the same

24 Tallinna Linnaarhiiv [Tallinn City Archives, henceforth TLA], 230-1- B.B.13, pp. 268-270, published in: Vanamölder, Kommunikatsiooniväli, p. 207.

25 "Hierbey gehet allso ein Exemplar von Donnerstag und Montag, wie man allenmahl continuiren wirdt". (TLA, 230-1-B.B.13, pp. 268-270, published in: Vanamölder, Kommunikatsiooniväli, p. 207). In Riga the newspaper was, until the end of 1686, published in accordance with the postal days of Mondays and Thursdays, after that, from 1687 to the end of 1703 , on Sundays and Wednesdays, most probably for the same reasons. From 1704 to 1710 the newspaper was again published on Mondays and Thursdays, being available for its readers at 10 a.m. See: Vanamölder, Kommunikatsiooniväli, p. 53 and Rigische Novellen Nr 104 (30 December 1703).

26 See Buchholtz, Geschichte der Buchdruckerkunst in Riga, p. 167; Taube, 'Rīgas pirmie', pp. 70-71; Simonov, 'K istorii', p. 122.

27 "Mit gehorsamer Bitte ihren selbst die große Ehre ihrer Benevolenz mir aber die Gütte zuerweisen, und hievon Euer Löbl. Bürgerschafft notification geschehen zulaßen, damit ob etwa ein oder ander diese Nouvellen verlanget, ich seine Nahmen wißen, und damit bedienen möge." (TLA, 230-1-BB.13, pp. 268-270, published in: Vanamölder, Kommunikatsiooniväli, p. 207). 
year, ${ }^{28}$ in which Prescher points out the task or duty (schuldigkeit) of supplying Narva with at least one copy of the newspaper. ${ }^{29}$ This document had been compiled as a reply to the letter from the Narva Town Council of 25 November and is therefore specific and sparse. Although the newspaper is not mentioned explicitly in the letter, it is hinted at by Prescher's request to notify him should the Town Council wish to have more than one issue [of the newspaper]. Knowing the contents of the advertising letter sent to Tallinn it can be assumed that sometime in the autumn an analogous letter was received by the Narva Town Council which responded favourably to Prescher. Due to the lack of further information, further assumptions cannot be drawn. It can be assumed, though, that the new Riga newspaper had found its way to Narva in 1680.

This newspaper was published under two titles, first as Rigische Montags (Donnerstags) Ordinari Post Zeitung, but sometime in March 1681 the name change took place, and the new Rigische Novellen differentiated itself from the predecessor by its volume, layout, typeset and contents, with more mundane and less sensational information. It has been assumed in the historiography that the change of name and contents meant the shift of publishing the newspaper from the royal printer to the town printer. ${ }^{30}$ It may be possible that the changes described above were caused by Prescher's attempt to make the newspaper more attractive to the readership. We know that due to the facelift of the newspaper and the change of the printer, Prescher negotiated with the Riga Town Council to receive an annual subsidy of 100 dalers for publishing the newspaper. The town, though, was willing to pay only half of this sum. ${ }^{31}$ Whether any agreement was reached cannot be deemed for certain at the present state of research.

Whether the abovementioned advertising had any positive result also remains unclear. In a petition sent to Charles XI in around 1681, ${ }^{32}$ Prescher

28 Narva magistrate, Suppliken - P, Band III: Eesti Ajalooarhiiv [Estonian Historical Archives, henceforth EAA] 1646.2.270, p. 53 .

29 "Ihro hochgeehrtes von 25en hujus hatt mir Anlass gegeben meine schuldigkeit abermahl mit diesem abzustatten; bitte nur nur an hand zu geben, ob Sie mehr alls ein Exemplar begehren, allsdann werde Ihnen nach dero gefallen allemahl bedienen. Hierbei gehen nun Doubletten ..." (EAA 1646.2.270, p. 53).

30 See Simonov, 'K istorii', pp. 126-128; Vanamölder, Kommunikatsiooniväli, pp. 28-31.

31 Buchholtz, Geschichte der Buchdruckerkunst in Riga, pp. 165-167.

32 RA, Livonica II, vol 141, Prescher to the royal majesty. The letter can be roughly dated by a trustworthy definition it contains: "Weiln E Königl Mayt mir auch vorm jahr allergnädigst vergönnet die Gazzetten in Riga drucken zulaßen", by which it could be assumed that the letter is from 1681 or 1682 . 
complained about the financial hardships. ${ }^{33}$ In order to acquire additional income he provided an inventorial plan with the aim of gaining greater control over foreigners visiting Riga, and of rearranging the work of the local post office. There is a separate item concerning the newspaper. According to Prescher the expenses overtook income which made further activities doubtful. ${ }^{34}$ To solve this problem, it was suggested that some of the money acquired as excise tax from shipping should be supplied for continuing the newspaper.

As a new item of information concerning the sale of news, it seems that Prescher wished to acquire the right to supply and distribute his letters and newspapers free of charge, and to be permitted to receive from Hamburg, free of charge, postal deliveries up to the weight of two lodes. ${ }^{35}$ As recompense he promised, despite the great pains and expenses, to forward on the postal days to Tallinn and Narva governorate offices "everything new that is not made public by printing". ${ }^{36}$

\section{Selling Exclusive Information: The Business of a Handwritten Newspaper}

Based on the petition, it became evident that aside from the publishing of newspapers, Riga (that is Prescher) supplied Estonian and Ingerian centres regularly with somewhat more exclusive information by means of a form of handwritten newspaper. The account books of the town of Narva provide evidence that during the last two decades of the seventeenth century among the 'expenses extraordinaire' there were annual subscriptions for ordering some kind of news media from Riga and Stockholm. What exactly was meant by the Riga newspapers (die Rigischen Advisen) remains unclear from the sources although attention should be given to the fact that the orders are detectable, according to the present data, to the period 1678 to $1682,{ }^{37}$ that is also for the

33 "Allso lege zu E. Königl Maytt hohen Gnaden mich in tiefster Erniedrigung fußfällig wieder, und bitte demüthligst umb ein stückchen brodt zum auffenthalt meines armseliges Lebens" (ibid.).

“... wiewoll die Unkosten die Einkünffte überwägen, und damit dem gemeine Wesen zum besten zu continuiren schie unertränglich ..." (ibid.).

35 One lode was approximately 10-12 grams.

36 "Wogegen ich gehalten seyn will, alle das Neue, waß durch den druck nicht publique zumachen, alle Post Tage dem Revalschen und Narwischen Gouvernement zu communicieren, worzu , weil die Mühe groß un eß offtmahle eine weitläuffige Arbeit ist, ich auf meine Unkosten iemand halten, und darunter nichts versammen will." (ibid.).

37 EAA 1646.1.1058, p. 32; Narva magistrate, kniga prikhoda i raskhoda gorodskikh summ, 1678; 1646.1.1062, p. 26, ibid., 1679; Latvijas Valsts Vēstures Arhīvs [Latvian State Historical 
period predating the press reform of Riga. The price of subscriptions was, in currency conversion accounts, 16 dalers or 16 dalers and 8 öres in silver. ${ }^{38}$ For subscriptions to the Swedish newspapers (die Stockholmche Advisen; Swänska Aviser), entries for a longer period of time can be found (1678 to 1696). ${ }^{39}$ For sending the Swedish newspapers, payments were made to Daniel (von) Möller, ${ }^{40}$ who worked at the end of the seventeenth century in the Stockholm post office holding various posts and who became the Stockholm postmaster at the beginning of the eighteenth century. ${ }^{41}$ According to the same sources, the subscription price of the Stockholm newspaper was 16 dalers, 21 and 1/3 öres in silver.

It seems possible that Narva ordered more than one copy of the newspaper since 16 dalers seems to be too high a price for an annual subscription of a single printed newspaper. In comparison, the Stockholm postmaster asked in the middle of the seventeenth century for a printed weekly Ordinari PostTijdender annual subscription of 2 dalers and 8 öres in silver. ${ }^{42}$ The Prescher printed newspaper appearing twice a week is in a comparable price bracket: 6 state dalers.

The fact that Narva continued to subscribe to the same priced Riga newspaper after 1680, and in addition corresponded with Prescher concerning the subscription of the new newspaper, seems to confirm the hypothesis that from Livonia additional and more exclusive news materials in shape of more

Archives, henceforth LVVA ], 7349-1-205, p. 28. lp., Vidzemes generālgubernātora pārvalde, Narvas pilsētas gada pārskati 1681; 7349-1-206, p, 28. lp., ibid., 1682.

38 At the beginning of 168 os, according to the exchange rate used in Narva, one state daler consisted of 62 öres. See Enn Küng, 'Riigitaalrite kasutusest Rootsi Läänemereprovintsides 17. sajandil', Ajalooline Ajakiri, 2 (2013), pp. 183-201 (198-200). <https://ojs.utlib.ee/ index.php/EAA/article/view/AA.2013.2.02>.

39 See EAA 1646.1.1058, p. 32, Narva magistrate, kniga prikhoda i raskhoda gorodskikh summ, 1678; LVVA, 7349-1-205, p. 28. lp., Narvas pilsētas gada pārskati, 1681; EAA 1646.1.1065, p. 17-18; LVVA, 7349-1-206, p. 28. lp., Narvas pilsētas gada pārskati, 1682; EAA 1646.1.1088, pp. 122-123, 1696 .

"För Swänske Adviserne och Correspondencen har Daniel von Möller bekomnit 2-e Ahr efter den Wexel och Advis sampt Order och quittens" (EAA 1646.1.1088, pp. 122-123).

See Teodor Holm, Sveriges allmänna postväsen: ett försök till svensk posthistoria IV: 1-3 (Stockholm: Norstedt, 1912-1916); 'Daniel Möller', in Yrjö Kotivuori, Ylioppilasmatrikkeli 1640-1852 (online version 2005) <http://www.helsinki.fi/ylioppilasmatrikkeli/henkilo .php?id=1875>. Last retrieved 12 March 2012.

See Paul Ries, 'The Politics of Information in Seventeenth-Century Scandinavia', in Brendan Dooley and Sabrina A. Baron (eds.), The Politics of Information in Early Modern Europe (London: Routledge, 2001), pp. 237-273 (240); Claes-Göran Holmberg, Ingemar Oscarsson and Jarl Torbacke, Den svenska pressens historia. 1: I begynnelsen (tiden före 1830) (Stockholm: Ekerlids förlag, 200o), p. 69. 
expensive handwritten newspapers were sent to Ingeria. Ordering of such news carriers for the town magistrates seems to have been common. ${ }^{43}$ For example, one of the means of acquiring additional income used by Stockholm postmasters from the mid seventeenth century to the beginning of the eighteenth century was the open sale of handwritten newspapers (Extract au $\beta$ einkommenden Correspondenz brieffen), which were also distributed in other areas of the State, including Livonia and Finland. ${ }^{44}$ According to Paul Ries, such newspapers were compiled during the seventeenth century by the post office workers with lower status, including postal clerks. ${ }^{45}$ The routine weekly marketable dispatching of information from Riga, an important centre of post and communication for the overseas provinces, basically meant that one of the areas of activities of the former postmaster - the compilation of news ceased in accordance with the royal order. Although Prescher noted Tallinn as the receiver of exclusive information, in the case of Narva no documentary evidence has been found.

\section{The End of Prescher's Activities}

The negative tone of the petition that was sent to the king and the fact that Prescher was actively seeking to find supplementary financing for his activities and actively advertised 'his' newspaper in both Tallinn and Narva suggest that by only holding the privileged status of the news purveyor he could not support himself adequately. There is no information regarding the king's reply. It is possible that in the end Prescher did not manage the task given to him very well which could explain why he left the post as soon as 1684 (the grounds given are getting married and moving to Saaremaa). ${ }^{46}$

43 Heiko Droste has shown that the price of handwritten newspapers in the Baltic sea region during the seventeenth and eighteenth century could have been four to ten times as much compared with the printed newspapers of the period: Heiko Droste, 'Die geschriebene Zeitung im 17. und 18. Jahrhundert. Ein öffentliches Nachrichtenmedium', Ajalooline Ajakiri, 3/4 (129/130) (2009), pp. 509-525 (515-517).

44 Heiko Droste, "Einige Wiener briefe wollen noch publiciren". Die geschriebene Zeitung als öffentliches Nachrichtenmedium', in Volker Bauer and Holger Böning (eds.), Die Entstehung des Zeitungswesens im 17. Jahrhundert: Ein neues Medium und seine Folgen für das Kommunikationssystem der Frühen Neuzeit (Bremen: Edition Lumière, 2011), pp. 1-23 (5-6).

45 See Ries, 'The Politics of Information', pp. 240-241.

46 Vanamölder, Kommunikatsiooniväli, p. 208. 
The news business during the seventeenth century was considered to be a subsidiary activity to postal duties. The petition sent in May 1681 to Magnus Gabriel De la Gardie by Statius Stein, who was closely connected to the Riga post office at that time and who later became the postmaster, seeking to move the privilege to print and distribute printed newspapers back to the post office, could be seen in the same context. ${ }^{47}$ The document stressed that such a privilege had always belonged to the postal office. ${ }^{48}$ When Prescher offered in his petition to be the reorganiser of the Riga post office he sought the same: that is, a return to the situation of pre-168o. It appears that the job of state news purveyor was at the beginning equally alien to both Prescher and the Riga postal office.

\section{The Tenure of Georg Ruvius and the Subscribers to Riga News Media}

After Prescher left the post in 1684, the castle court assessor Georg Ruvius was appointed to the post of Riga newspaper purveyor. The aim of the royal privilege dated 18 October of the same year sought to ensure the continuation of the already existing arrangement. ${ }^{49}$ The document stated that only Ruvius had the right to publish weekly a newspaper in Riga. It was strictly forbidden to publish or distribute any other newspaper. As for possible competing interest groups, the privilege, as with the 1680 royal order, lists separately printers and postal workers. The privilege also ensured the continuation of control of the central power on the newspaper because, although Ruvius is described as a "trustworthy person and long-time servant of the crown", the Rigische Novellen was subjugated to the censorship of the office of the governor-general. ${ }^{50}$

As before, there was no annual salary or other recompense from the crown. Nevertheless, it seems that the financial position of Ruvius was better than his predecessor's and the job of state news purveyor did not cause him any difficulties. Very little is known about his tenure: there are no extant petitions,

47 See Enn Küng, 'Johan Lange's Inspection of the Estonian and Livonian Postal Systems, 1687-88', in Heiko Droste (ed.), Connecting the Baltic Area. The Swedish Postal System in the Seventeenth Century (Huddinge: Södertörns högskola, 2011), pp. 99-122 (108).

48 RA, De la Gardieska samlingen, E 1567, Statius Stein till Magnus Gabriel De la Gardie, Riga, 20 May 1681; Heiko Droste, 'The Terms of Royal Service: Post Servants' Finances, c. 170o', in ibid., Connecting the Baltic Area, pp. 123-174 (167).

EAA, 278.1.IV:25:2, p. 16.

50 Ibid. 
complaints or other such documents, and this suggests that, at the present state of research, he did not encounter major problems with his work. The official newspaper of Riga continued its regular appearance twice a week until the end of Swedish rule in 1710.

By the end of the 168os, Ruvius had acquired, in addition to the local Riga consumers, a notable circle of subscribers in the other overseas provinces. Among the documents of the postal inspection in Estonia and Livonia, carried out by the central power in 1687 and 1688 , is a list of people who received free letters and newspapers (avis) from Riga between 23 January to 6 February. ${ }^{51}$ This list reflects the period when Johan Lange visited and inspected the Riga post office. Addressees - approximately 25 people - lived in Tallinn, Narva, Tartu, Kuressaare (Arensburg), Pärnu and Valmiera (Wolmar). All these towns (excluding Kuressaare in Saaremaa) were situated along the main roads connecting the provincial centres. Along these same roads the official state postal connection operated. ${ }^{52}$ From the point of view of press history, the extant list is very interesting and valuable since so little is known about the readership of early modern newspapers. The people listed in the documents deserve individual and detailed analysis, which would enable one to sketch in more detail the prosopographical portrait of the early modern newspaper reader.

A cursory look tells us that higher ranking citizens were among the subscribers of the newspaper. For example, the addressees in Narva include burghers Ludolf Zander, Ulrich Herbers and Hans Fonne..$^{53}$ There is no doubt that all these men were part of the Narva elite: Zander was a goldsmith and Elder of a Guild, Herbers a syndic, Town Council secretary and burgomaster, and Fonne a renowned merchant. ${ }^{54}$ In other towns as well as the traditional subscribers, the list contained merchants; however, in Pärnu the news media were ordered separately by the Town Council. A separate group was formed by postmasters (Andreas Max in Tartu and Lorenz Hindrich in Pärnu) and Tallinn printer Christoph Brendeken who were typical early modern news purveyors. The newspapers were ordered by several other people holding official posts like royal fiscal officer Philippius Schirm in Pärnu, the secretary of the Tartu

$5^{1} \quad$ See RA, Kanslikollegium G II:fi and compare with Küng, “.... mugavamaid teid”, p. 25.

52 Küng, 'Johan Lange's Inspection', pp. 111-112.

53 Ludolf Zander, Ulrich Habers [Herbers], Hanß Fonne - compare Ludolf Zandler (nr 8og), Ulrich Herbers ( $\mathrm{nr} 7 \mathrm{7}_{7}$ ) and Hans Fonne (nr 751) in Dirk-Gerd Erpenbeck and Enn Küng, Narvaer Bürger- und Einwohnerbuch, 1581-1704 (Dortmund: Forschungsstelle Ostmitteleuropa, 200o).

54 Ibid. See also Dirk-Gerd Erpenbeck and Roland Seeberg-Elverfeldt, Narva 1581-1721. Quellen zur Geschichte der Stadt in schwedischer Zeit (Dortmund: Forschungsstelle Ostmitteleuropa, 1993), pp. 75-79. 
court of appeal Caspar Johann Knifig, and literati: a professor of Tartu University, Michel Dau, and a professor and later rector of Tallinn Gymnasium, Johann Rudolf Brechm. There are also military officials among the list: for example, a certain Albedyl from Valmiera. ${ }^{55}$ Even this brief sampling shows that the background of the newspaper readers was diverse yet representative of all the groups in the society (officials, military men, clerics, intelligentsia) who are typically considered the news consumers during the early modern period. ${ }^{56}$

At the present stage of research, it is impossible to be certain, whether the forwarded newspaper was Rigische Novellen or, for example, a 'package' of handwritten news items. The addressees were definitely the clients of Ruvius which is confirmed by the final report that Lange wrote after his inspection in March 1688. The text stresses that only Ruvius was permitted to bring newspapers to Riga free of charge and to make abstracts from the foreign newspapers, to let them be printed in Riga and to dispatch them all over the country tax free. ${ }^{57}$

Due to the lack of sources it cannot be claimed that Christoph Prescher managed to create such a vast network of subscribers during the beginning of 1680 . Nevertheless, looking at his activities and the fact that the only legal way to quench the thirst for news was to turn to the state newspaper purveyor in Riga, it seems that the business was on its feet at least by the end of the same decade. The materials of Lange's postal inspection confirm the concept of the Riga newspaper as the only official news medium for the Swedish overseas provinces. ${ }^{58}$ Assuming that at the end of 1680 the annual subscription of the Riga newspaper still cost 6 dalers, we can make a reasonable calculation, based on the number of known subscribers, that the turnover of the state newspaper purveyor was approximately 150 dalers per annum, which would

55 According to the source the people receiving the newspaper in Tallinn were Hindrich Hakelman; Christoffer Brendeken; Joh. Cahillis; Hermann Hentenberg [Herm Hortenb]; Michel Guntery; prof. Bechm (RA, Kanslikollegium G II:fi); compare for example Johann Clayhilles (nr 1092), Hinrich Hakelmann (nr 906), Christof Brendeken (nr 910) in Georg Adelheim, Das Revaler Bürgerbuch 1624-169o nebst Fortsetzung bis 1710 = Tallinna kodanikkuderaamat 1624-169o ühes jätkuga kuni 1710-ni (Tallinn: Eesti Kirjastus Ühisus, 1933). The last one on the list is presumably a professor and later rector of the Tallinn Gymnasium Johann Rudolf Brehm (?-1730): Endel Laul and Jaan Tamm, Gustav Adolfi Gümnaasium 375 (Tallinn: Eesti Entsüklopeediakirjastus, 2006), p.40.

56 Kaspar Stieler, Zeitungs Lust und Nutz (Vollständiger Neudruck der Originalausgabe von 1695, hg. von Gert Hagelweide) (Bremen: C. Schünemann, 1969), pp. 68-72.

57 RA, Kanslikollegium G II:fi, Johann Lange's report to Chancery Board 15 March 1688; compare Küng, “'... mugavamaid teid”', pp. 22-23.

$5^{8}$ Vanamölder, Kommunikatsiooniväli, pp. 192-197. 
be accrued by the profit made from selling the newspaper in Riga, exceeding the annual hundred daler salary that Prescher requested from the Riga Town Council.59

\section{The Tallinn Printer Christoph Brendeken and Reval(i)sche Post-Zeitung}

The subscriber list compiled by Johann Lange also includes the Tallinn Gymnasium printer Christoph Brendeken who in Estonian press history is known as the publisher of the second newspaper issued in the Swedish overseas provinces: Reval $(i)$ sche Post-Zeitung, published twice a week. ${ }^{60}$ The Tallinn newspaper cannot be treated as an independent publication since the comparison of the contents of its extant annual volumes with the Riga newspaper shows that Reval( $i$ )sche Post-Zeitung was mainly a verbatim reprint of the Rigische Novellen, albeit in a somewhat abridged version. ${ }^{61}$ Reval $(i)$ sche Post-Zeitung was usually a reprint of the Riga newspaper issued within a week and never based on a chronologically older issue, as illustrated by the schema below.

TABLE 12.1 Sample of the transformation of the Riga newspaper into the Tallinn newspaper in 1692 as shown by four consecutive numbers. Vanamölder, 'Was für eine Zeitung,' p. 82.

\section{Rigische Novellen (number, date and weekday)}

No 33, 24.04.1692, Sunday

No 34, 27.04.1692, Wednesday

No 35 , 01.05.1692, Sunday

No 36, 04.05.1692, Wednesday
Reval(i)sche Post-Zeitung (number, date and weekday)

As the schema shows, the Riga newspaper issue of Sunday transformed into the Tallinn Thursday issue, and Rigische Novellen published on Wednesday

59 Buchholtz, Geschichte der Buchdruckerkunst in Riga, pp. 165-167.

60 See, for example, Friedrich Puksoo, 'Die Buchdrucker Brendeken in Estland', Gutenberg Jahrbuch, 9 (1934), pp. 199-207; Vanamölder, Kommunikatsiooniväli, pp. 23, 35.

61 Vanamölder, Kommunikatsiooniväli, pp. 181-191; Kaarel Vanamölder, 'Was für eine Zeitung wurde in Reval am Ende der schwedischen Zeit gelesen?', Forschungen zur baltischen Geschichte, 6 (2011), pp. 61-84. 
became Reval(i)sche Post-Zeitung of Monday. To bring the Riga newspaper to Tallinn and to reprint it took therefore on average five to six days. ${ }^{62}$ The publication days of both newspapers coincide with the post dispatching days in Riga and Tallinn: in Riga the postal days were Sunday and Wednesday, in Tallinn Thursday and Monday. On these days the mail, including letters that had arrived at Riga earlier, was dispatched. ${ }^{63}$

A regular and dependable operating postal connection with Riga made it, logically, possible to issue Reval(i)sche Post-Zeitung so that in the eyes of its readers its contents did not lose any topicality, which, by default, is proven by the fact that the newspaper continued for at least 22 years. In this respect the Tallinn newspaper symbolises the well-functioning postal connections between provincial centres at the end of the seventeenth century. The posthaste galloping and horn-blowing post courier image on the heading of the Reval $(i)$ sche Post-Zeitung carried in a direct sense the message of the news arriving with the utmost speed. ${ }^{64}$ For publishing twice weekly a newspaper in Tallinn, which was one of the 'end-stations' of the Estonian and Livonian overland postal chain, there was hardly any other technical alternative. The contact along the postal network reaching abroad was maintained overland and was in many aspects dependent upon the role of the Riga post office as a mediator. Only during the navigation season were private letters from Tallinn dispatched directly to Western Europe. ${ }^{65}$

Evidently the postal connection between Riga and Tallinn in the seventeenth century had occasional failures. In 1680 Prescher admitted that problems occurred depending on the season with the postal connection to Tallinn which also affected the distribution of the Riga newspaper. On these occasions Reval( $(i)$ sche Post-Zeitung numbers had been compiled based on the newspapers issued in Hamburg that had reached Tallinn. ${ }^{66}$ Transcribing newspapers was a commonly known practice during the early modern period: so called 'pirated publications' had been made, for example, of Hamburg's Nordischer Mercurius $^{67}$ and Stockholm Ordinari Post-Tijdender. ${ }^{68}$

\footnotetext{
62 See Vanamölder, 'Was für eine Zeitung', pp. 68-82.

63 Received letters concerning management and legal issues, April 1689. EAA 1.2.491. L 288.

64 See Marianne Larsson, 'Livery Coat, Postal Horn, and the National Coat of Arms. The Material's Agency for the Honour and Protection of Seventeenth-Century Post-Carriers', in Droste, Connecting the Baltic Area, pp. 175-195 (180).

65 Küng, “'... mugavamaid teid”, p. 26.

66 Vanamölder, 'Was für eine Zeitung', pp. 73-78.

67 Böning and Moepps, Hamburg, pp. 25-26.

68 Ries, 'The Politics of Information', p. 243.
} 
Reval(i)sche Post-Zeitung may be seen as a clever compromise between technical possibilities and contemporary 'press politics' in order to satisfy the hunger for news within the town. Multiple objectives could be achieved by the transcription of the Riga newspaper: firstly, it provided an easy option for publishing a regular newspaper, and secondly, it helped prevent the intervention of the local censoring authorities. Taking into consideration how attentive the central power and its representatives were towards publishing regular news media in Stockholm and Riga, the printing of Reval( $i$ )sche Post-Zeitung must have taken place if not upon the initiative of the central power and its representatives, then at least with their knowledge and acceptance. Unfortunately, no additional sources, revealing anything on the motives of establishing the Tallinn newspaper, have been revealed so far. The role of Reval $(i)$ sche PostZeitung continues to be shown by the sheer number of the extant newspapers.

As a centrally controlled newspaper transcript the publication mechanism of Reval(i)sche Post-Zeitung can be compared with the press politics applied in France. The dissemination of the only printed, legal and regular French newspaper, the Gazette, had its geographical limits. Due to this, the provinces could, upon having purchased a licence, publish exact reprints of the newspaper. By the last decade of the seventeenth century the central power had issued 13 such printing licences. ${ }^{69}$ The motherland and the provinces of the Swedish state were both connected and separated by the sea. Application of the described 'French model' in both Riga and Tallinn, based on a newspaper published in Stockholm once a week, would not have been logistically possible. At the same time, the press politics of both states and the character of their official newspapers have several similar traits. Rigische Novellen was established for political reasons: to compete with the Königsberg newspapers published twice a week. It is possible that this timeframe dictated how often the Livonian and Estonian newspapers were published. Based on the 'French model', Rigische Novellen could be seen as the official newspaper of the Baltic provinces, which licensed transcript appeared as Reval(i)sche Post-Zeitung in Tallinn, and which, in all likelihood was also available in Narva.

\section{Conclusion}

Up to 1680 information trading in Riga was typical of early modern market towns where post masters and printers were selling different news media

69 Jean-Pierre Vittu, 'Instruments of Political Information in France', in Brendan Dooley and Sabrina A. Baron, The Politics of Information in Early Modern Europe (London and New York: Routledge, 2001), pp. 160-179 (172). 
and compiling new ones. The probably hand-written news media compiled in Riga were ordered by Narva prior to 1680 and this activity continued later. The intervention of the royal power changed the existing information market, pushing aside the traditional representatives of the business by pressure from the central power, and this created a state monopoly of newspaper publishing and news mediation. With these steps taken, the trading of news in Riga was brought closer to the practices in Stockholm.

In 1680 the Riga news market was subjected to the control of the central power by royal order and the privileged professional monopoly of the state newspaper purveyor was established. This professional monopoly continued until the end of Swedish power in the region in 1710 . The newspapers compiled and printed in Riga at this time, Rigische Montags (Donnerstags) Ordinari Post Zeitung (1680-1681) and its successor Rigische Novellen (1681-1710) are examples of publications controlled by the central power whose contents were controlled by state censorship.

In countries with absolutist power, the central power sought to control the information targeted for public consumption, subjugating the issuing of newspapers to direct and rigid state control. The regulating of the Riga news market, imposed by the central power in 1680, was presumably not an accidental event but was part of the consolidation of the power of the Swedish king, Charles XI.

The archives providing insights into the service of Christoph Prescher, the first state newspaper purveyor, from 1680 to 1684 , allow us to take a closer look at the marketing strategies of an early modern newspaper purveyor as he distributed his goods, the news media. To alleviate financial and economic difficulties, he endeavoured to find readers for his newspaper outside Riga and Livonia by advertising the new newspaper in the centres of the neighbouring provinces, Tallinn and Narva, and in 1681 he changed the name and appearance of the newspaper. Approximately a year after the publication of the newspaper, Prescher encountered problems. To break out of the restrictive role of the news purveyor, Prescher sought additional outlets for his activities offering, for example, to be the reorganiser of the Riga post office and wishing thereby to re-establish the situation prior to 1680 . The Riga post office, on its own behalf, was seeking to re-establish its previous right to trade news. It seems that the post of a privileged news purveyor was equally unfamiliar to Prescher and the Riga post office.

The problems of the Riga state news purveyor seem to have been solved by the end of the 168 os since, during the tenure of Georg Ruvius (1684-1710), the newspaper had acquired a large subscription network in Estonia, Livonia and Ingeria in addition to its local town readership. The extant data reveals up to 25 individuals who received newspapers from Riga at the beginning of 1688 . 
This is a valuable piece of information since usually nothing is known of the readers of the early modern newspaper. The important role of Riga as a news controlling and forwarding centre in Swedish overseas provinces is reflected in the publication history of the Tallinn newspaper, Reval( $i$ )sche Post-Zeitung (1689-1710). The Tallinn newspaper cannot be treated as an independent publication because the comparison of its extant issues shows that the contents of Reval(i)sche Post-Zeitung with the Rigan newspaper were mainly verbatim reprints of Rigische Novellen with slight cuts. The regular and unhindered postal connection with Riga permitted publishing of Reval(i)sche Post-Zeitung, so the contents did not lose their relevance in the eyes of the readers: a fact proven by the publication of the Tallinn newspaper for at least 22 years. As a transcription of a centrally controlled newspaper, the publication mechanism of Reval( $i$ )sche Post-Zeitung is similar to the publication politics applied in France. Since the distribution of the only legal regular printed newspaper in France - the Gazette - had geographical limits, the provinces were permitted to publish exact reprints of the newspaper if a special licence was acquired. Based on the 'French model' the Rigische Novellen could be seen as the official newspaper of the Baltic provinces which was transcribed and published as Reval(i)sche Post-Zeitung in Tallinn, and was presumably also available in Narva. Reval( $i)$ sche Post-Zeitung therefore represents a clever provincial compromise between technical possibilities and existing press politics that was applied to quench the information thirst of Tallinn. By using the transcript of the Riga newspaper several objectives could be achieved: guaranteeing an easy solution for publishing a regular newspaper and preventing the interference of local censorship. 